\title{
KESEJAHTERAAN MUSTAHIQ DAN NON MUSTAHIQ PERSPEKTIF MAQAASHIDUS SYARIAH PADA DOMPET DHUAFA DAN PROGRAM NASIONAL PEMBERDAYAAN MASYARAKAT
}

\author{
Roisiyatin', Jamaludin² \\ Institut Umul Quro Al-Islami Bogor \\ Jl. Mohnoh Nur No.112, Leuwiliang, Bogor, Jawa Barat 16640 \\ roisiyatin@iuqibogor.ac.id1, jamaludin@iuqibogor.ac.id²
}

Received: 23 April 2020; Revised: 30 May 2020; Published: 20 June 2020

ABSTRAK

Penelitian ini bertujuan untuk menganalisis perbandingan antara zakat produktif program pemberdayaan petani sehat (P3S) Dompet Dhuafa dan bantuan zakat dan non mustahiq anggota program nasional pemberdayaan masyarakat (PNPM) dengan bantuan non zakat perspektif maqaashidus syariah. Hasil analisis uji beda ANOVA diperoleh tingkat signifikansi sebesar 0,010 berada dibawah 0,05, dengan demikian terdapat perbedaan signifikan antara variabel bantuan zakat $(X)$ terhadap kesejahteraan mustahiq dari sudut pandang maqaashidus syariah ( $\mathrm{Y}$ ) dibandingkan dengan bantuan kepada non mustahiq. Dana zakat memberikan kontribusi kesejahteraan kepada mustahiq sebesar $87 \%$, sedangkan dana non zakat memberikan kontribusi kesejahteraan kepada non mustahiq sebesar $59 \%$. Kesimpulan penelitian terdapat perbedaan kesejahteraan antara mustahiq dan non mustahiq. Sudut pandang maqaashidus syariah bahwa zakat memberikan kesejahteraan secara agama, akal, jiwa, harta dan keturunan. Zakat sebagai syariat dari Allah swt untuk kemaslahatan umat manusia dapat memenuhi kelima aspek maqaashidus syariah dalam studi kasus yang dilakukan pada mustahiq P3S Dompet Dhuafa dan non mustahiq PNPM.

Kata kunci : zakat; kesejahteraan; mustahiq.

\begin{abstract}
This study aims to analyze the comparison between the productive zakat of the empowerment of healthy farmers (P3S) Dompet Dhuafa and the donation of zakat and non-mustahiq members of the national community empowerment program (PNPM) with the help of non-zakat perspective Maqaashidus sharia. ANOVA different test analysis results obtained a significance level of 0.010 under 0.05, thus there is a significant difference between the variables of zakat $(X)$ on the welfare of mustahiq from the perspective of maqaashidus sharia $(Y)$ compared to assistance to non mustahiq. Zakat funds contribute welfare to mustahiq by $87 \%$, while non-zakat funds contribute welfare to non mustahiq by 59\%. The conclusion of the study there are differences in welfare between mustahiq and non mustahiq. The perspective of maqaashidus sharia is that zakat provides welfare in terms of religion, reason, soul, wealth and progeny. Zakat as a Shari' a from Allah Almighty for the benefit of mankind can fulfill the five aspects of maqaashidus sharia in a case study conducted on P3S Dompet Dhuafa and non mustahiq PNPM.
\end{abstract}

Keywords: zakat; welfare; mustahiq. 


\section{PENDAHULUAN}

Permasalahan ekonomi akan terus terjadi dari masa ke masa, karena ekonomi merupakan salah satu faktor terpenting terhadap kemajuan suatu pemerintahan maka konsep kesejahteraan terus dikembangkan. Tujuan kesejahteraan yang pada mulanya hanya melihat indikator pembangunan ekonomi telah berubah menjadi indikator (Qordhowi,2005) pembangunan manusia karena tantangan pembangunan juga terjadi sangat dinamis.Dari tahun ke tahun berbagai upaya terus dikembangkan untuk mewujudkan pembangunan yang bertujuan mengentaskan kemiskinan. Berangkat dari target pembangunan manusia yang telah dikembangkan, pembangunan manusia yang telah digagas dan dikembangkan tersebut tidak membawa dampak pada kesejahteraan lingkungan, dimana yang terjadi adalah bahwa dari waktu ke waktu terjadi kerusakan lingkungan yang mengkhawatirkan.

Kesejahteraan berkelanjutan dapat terhambat oleh ketimpangan ekonomi yang terjadi, sehinggadibutuhkan instrumen keadilan yang sifatnya alokatif dan distributif. Maka disini lembaga zakat akan memastikan bahwa ada redistribusi bersamaan pendapatan dan output dalam mendukung orang yang kurang beruntung di tingkat mikro. Redistribusi tahunan kekayaan dan redistribusi tersebut akan menentukan keadaan makroekonomi(Tahir: 2003).

Upaya meningkatkan kesejahteraan tersebut, pemerintah sebagai regulator memerlukan instrumen. Salah satu instrumen kebijakan publik yang ditawarkan Islam untuk Indonesia yang mayoritas penduduknya muslim ini adalah zakat, dimana zakat yang merupakan rukun Islam keempat tersebut adalah mutlak wajib. Berdasarkan data nasional zakat memiliki potensi sangat besar. PIRAC (Public Interest Research and Advocacy Center) menemukan potensi zakat mencapai $\mathrm{Rp} 4,3$ triliun. Menurut survey terbaru yang dilakukan Badan Amil Zakat Nasional (Baznas) bersama dengan Institut Pertanian Bogor (IPB) dan IRTI-IDB pada 2011 menemukan bahwa potensi zakat nasional mencapai $\mathrm{Rp} 217,3$ triliun dari total pendduduk muslim di Indonesia. Maka, hasil penelitian tersebut menunjukan bahwa zakat apabila dikelola dengan baik, mampu menjadi kekuatan dalam membangun kondisi perekonomian suatu negara dan masyarakat.

Conference Papers of Fourth International Conference on Islamic Economic and BankingdiLoughborough University pada tahun 2000 menyebutkan bahwa zakat merupakan instrumen penting dan signifikan dalam upaya meningkatkan kesejahteraan masyarakat miskin di dalam Islam yang 
Roisiyatin,: zakat; welfare; mustahiq.

merupakan fungsi redistribusi income. Program pemberdayaan zakat kini telah banyak bertransformasi dari ranah amal-sosial ranah pemberdayaan dan pengembangan masyarakat. Dengan demikian, terbuka peluang yang lebar untuk mengkoordinasikan zakat dengan program-program pengentasan kemiskinan sekaligus pemberdayaan masyarakat berbasis maqaashidus syariah dimana faktor keberlangsungan lingkungan termasuk di dalamnya.

Penelitian ini memiliki dua pertanyaan inti yang dijawab dalam sebuah analisis perbandingan. Yang pertama apakah program zakat produktif pada Program Pemberdayaan Petani Sehat (P3S) Dompet Dhuafa telah memberikan kesejahteraan kepada masyarakat sesuai konsep maqaashidus syariah. Dan yang kedua, apakah ada perbedaan dan seberapa jauh perbedaan kesejahteraan masyarakat ekonomi lemah kategori mustahiq anggota P3S Dompet Dhuafa dengan bantuan zakat dan non mustahiq anggota Program Nasional Pemberdayaan Masyarakat (PNPM) dengan bantuan non zakat perspektif maqaashidus syariah.

Perbedaan signifikan penelitian dengan penelitian terdahulu, bahwa penelitian ini menggunkan analisis uji beda ANOVA yang tidak dipergunakan dalam penelitain sebelumnya, kemudian perbedaan lainya bahwa penelitian ini mengukur terhadap kesejahteraan mustahiq dari sudut pandang maqaashidus syariah memperbandinkn bantuan kepada mustahiq bandingkan dengan bantuan kepada non mustahiq. Skoring kuesioner menyatakan dana zakat memberikan kontribusi kesejahteraan kepada mustahiq sebesar 87\%. Sedangkan dana non zakat memberikan kontribusi kesejahteraan kepada non mustahiq sebesar $59 \%$. 


\section{LANDASAN TEORI}

Zakat merupakan ibadah di bidang harta yang kaitannya bukan saja kepada Tuhan, tetapi juga berimplikasi kepada sesama manusia secara keseluruhan (Qadir: 1998). Al Ghazali dan Asy-Syathibi, Karim (2003) menjelaskan kesejahteraan suatu masyarakat tergantung kepada pencarian serta pemeliharaan lima tujuan dasar, yaitu: pertama : agama (din), kedua : jiwa (nafs), Ketiga : akal (aql), keempat : keturunan (nasl), serta kelima : harta (maal). lima tujuan dasar tersebut adalah kebutuhan dasar manusia, merupakan kelompok mutlak harus dipenuhi sehingga manusia dapat hidup bahagia di dunia sampai akhirat. jika kesejahteraan dinilai dari segi materi, dengan penghasilan yang mencukupi kebutuhan dasar seseorang dan keluarganya, biasanya cenderung akan melahirkan ketenangan dalam hidup dan kehidupannya, termasuk mempertahankan dan menjalankan kegiatan agamanya (Hafidhuddin, 2007). Seperti kewajiban zakat yang merupakan salah satu syariat yang ditetapkan setelah shalat, yaitu untuk melindungi agama, melindungi jiwa, melindungi keturunan, melidungi akal serta melindungi harta. Syariat Islam pada dasarnya ditetapkan untuk menjaga keberlangsungan kehidupan dasar manusia. Gambarannya seperti skema di bawah ini.

\section{Gambar 2.3 Maqaashidus Syariah}

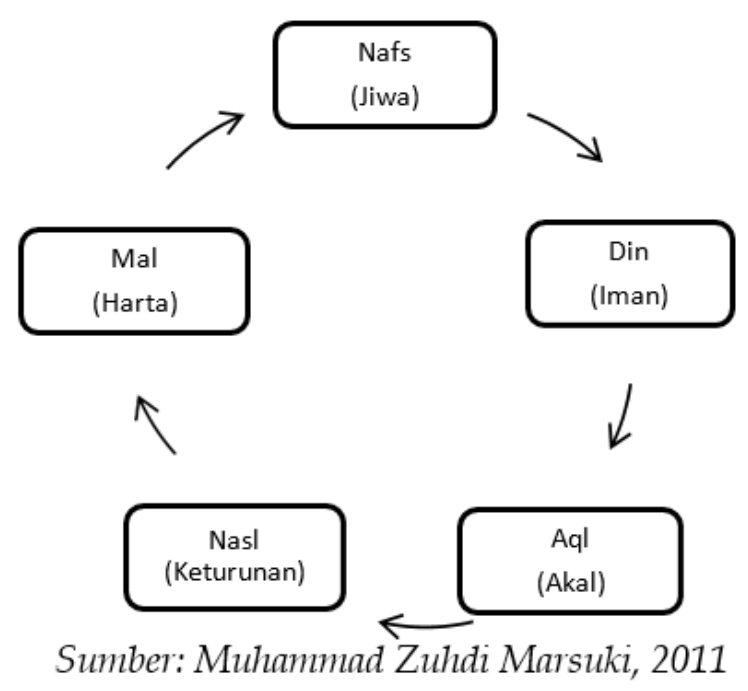

Berdasarakan gambar di atas, bahwa Islam mempunyai banyak hal mngenai peraturan kegiatan manusia, bukan hanya mencakup aspek ekonomi saja. Syariah yang ditetapkan mencakup dua aspek, yaitu aspek ibadah dan muamalah. Tujuan dari syariah adalah kesejahteraan manusia, yaitu apakah barang tersebut mempunyai utilitas. Banyak sekali kriteria 
Roisiyatin,: zakat; welfare; mustahiq.

yang menjadi dasar seseorang memutuskan apakah suatu barang mempunyai utilitas. Tidak demikian halnya dengan maslahah. Kriteria maslahah ini adalah mampu meningkatkan konsistensi dan validitas kebijakan ekonomi karena kriteria untuk pengambilan keputusan adalah telah diketahui.

\section{Konsep Kesejahteraan Perspektif Maqaashidus syariah Sustainable Development (Hifdzun nasl) Dalam Maqaashidus Syariah}

Salah satu aspek pemeliharaan dalam konsep maqaashidus syariah adalah hifdzun nasl (pemeliharaan keturunan) yang di dalamnya mencakup pemeliharaan kelestarian dan keberlangsungan kehidupan yang merupakan tujuan dari konsep pembangunan kesejahteraan berkelanjutan (sustainable development). Hasan (2007), Islam memperhatikan pembangunan ekonomi secara pertumbuhan kematangan manusia, kemajuan materi harus menunjang kematangan spiritual. tujuan pentingharus menjadi prioritas sebagaimana: pertumbuhan harus diikuti dengan tenaga kerja penuh, stabilitas ekonomi, keadilan distributif dan kepedulian terhadap alam. Hal tersebut termasuk dalam salah satu variabel yang terkandung dalam maqaashid syariah berupa hifdzun nasl (penjagaan keturunan), yang tidak terlepas dari norma-norma syariah.

\section{METODE PENELITIAN}

Jenis penelitian ini kuantitatif. Teknik analisis data statistic SPSS dengan pendekatan studi eksploratif dan komparatif. teknik pengumpulan data penelitian ini adalah data primer berupa kuesioner dan wawancara, data sekunder dokumen-dokumen yang berkaitan dengan P3S Dompet Dhuafa yang disalurkan melalui pemberian zakat produktif. Sampel yang digunakan adalah 60 responden yang terdiri dari 30 responden mustahiq Program Pemberdayaan Petani Sehat (P3S) Dompet Dhuafa dan 30 responden non-mustahiq Program Nasional Pemberdayaan Masyarakat 


\section{HASIL PENELITIAN DAN PEMBAHASAN}

Uji Validitas Intrumen Penelitian

Kuesioner sejumlah 30 pertanyaan dengan 60 responden terdiri atas 30 responden mustahiq dan 30 responden non mustahiq dinyatakan reliabel jika mempunyai nilai koefisien alpha yang lebih besar dari 0,60 $(>0,60)$. Hasil selengkapnya bisa diperhatikan pada tabel berikut :

\section{Tabel 4.7 Hasil Uji Reliabilitas Instrumen Reliability Statistics}

\begin{tabular}{ccl}
\hline & Cronbac & \\
& h's Alpha & \\
& Based on & \\
Cronbach & Standardi & \\
's & zed & \\
Alpha & Items & N of \\
& & Items \\
\hline .848 & .791 & 25 \\
\hline
\end{tabular}

Pada tabel c

reliabel karena mempunyai nilai koefisien alpha yang lebih besar dari 0,60 (>0,60) sehingga dinyatakan reliabel.

Uji Hipotesis Menggunakan ANOVA

Hasil pengujian hipotesis secara simultan dapat dilihat pada tabel sebagai berikut:

Tabel 4.13 Hasil Uji Beda

ANOVA

\begin{tabular}{|c|c|c|c|c|c|}
\hline & $\begin{array}{l}\text { Sum of } \\
\text { Squares }\end{array}$ & $D f$ & $\begin{array}{l}\text { Mean } \\
\text { Square }\end{array}$ & $F$ & Sig. \\
\hline $\begin{array}{l}\text {;.Betwee } \\
n \\
\text { Groups }\end{array}$ & 3.344 & 14 & .239 & $\begin{array}{l}2.4 \\
97\end{array}$ & .010 \\
\hline $\begin{array}{l}\text { Within } \\
\text { Groups }\end{array}$ & 4.306 & 45 & .096 & & \\
\hline Total & 7.650 & 59 & & & \\
\hline
\end{tabular}

a. Predictors: (Constant),zakat

b. Dependent Variable:kesejahteraan

Diketahui dari hasil tabel diatas bahwa tingkat signifikansinya adalah 
Roisiyatin,: zakat; welfare; mustahiq.

0,010 yang berada di bawah 0,05, artinya terdapat perbedaan signifikan antara variabel bantuan zakat $(X)$ terhadap kesejahteraan mustahiq dari sudut pandang maqaashidus syariah (Y) dibandingkan dengan bantuan kepada non mustahiq.

\section{Deskripsi Hasil Penelitian}

Dari analisis data penelitian seperti yang telah dikemukakan di atas bisa diperhatikan hasil penelitian yaitu: Apakah terdapat perbedaan yang signifikan antara bantuan dana hibah dengan pendekatan yang sama yang diberikan kepada non mustahiq dari sudut pandang magaasihidus syariah.

Pada nilai koefisien yang telah diuraikan sebelumnya menunjukan bahwa:

Y Mustahiq $=X 1+X 2+X 3+X 4+X 5$
Y Non Mustahiq $=X 1+X 2+X 3+X 4+X 5$

Dimana:

$\mathrm{Y}=$ Kesejahteraan

X1 = Pemeliharaan Agama

X2 = Pemeliharaan akal

X3 = Pemeliharaan harta

X4 $=$ Pemeliharaan harta

X5 = Pemeliharaan keturunan

Untuk diidentifikasi perbedaan kesejahteraan diantara mustahiq perbedaan kesejangan diantara mustahiq dan non mustahiq dari kelima pengukuran mustahiq syariah. Kemudian setelah diidentifikasi perbedaannya, maka diidentifikasi seberapa signifikan perbedaan variabel independent terhadap variabel dependentnya dari nilai ANOVA. Sebagaimana sudah diuraikan di atas, bahwa nilai koefisien signifikansi 0,010 artinya perbedaan kesejahteraan yang signifikan antara mustahiq dan non mustahiq dengan bantuan dan pendampingan yang hampir sama.

Hasil perhitungan skoring di pembahasan sebelumnya direpresentasikan bahwa 30 responden mustahiq yang memperoleh bantuan zakat dari Dompet Dhuafa memenuhi kriteria sejahtera karena memiliki skor di atas 50 dan dibutikan dengan nilai signifikansi sebesar 0,010. Sedangkan data non mustahiq yang memperoleh bantuan dari PNPM direpresentasikan bahwa 30 responden non mustahiq sejumlah 70\% memenuhi kriteria sejahtera karena memiliki skor di atas 50 dan dibutikan dengan nilai signifikansi sebesar 0,010. Perbedaan mustahiq dan non mustahiq dapat 
dilihat dalam tabel perbandingan di bawah ini:

Tabel 4.16 Perbedaan persentase kesejahteraan mustahiq dan non mustahiq dari sudut pandang pemeliharaan agama

\begin{tabular}{l|l|l|l}
\hline $\begin{array}{l}\text { Total } \\
\text { Mustahiq }\end{array}$ & 134 & $\begin{array}{l}\text { Total Non } \\
\text { Mustahiq }\end{array}$ & 132 \\
\hline Presentasi & 89,3333 & Presentasi & 88 \\
\hline
\end{tabular}

Dari tabel di atas diperoleh hasil persentase kesejahteraan mustahiq dari sudut pandang pemeliharaan agama sebesar 89,3\%, sedangkan hasil untuk non mustahiq adalah sebesar $88 \%$. Perbedaan keduanya tidak signifikan sehingga variabel pemeliharaan agama pada zakat maupun bantuan non zakat hampir sama memberikan pemeliharaan agama kepada mustahiq dan non mustahiq.

Tabel 4.17 Perbedaan persentase kesejahteraan mustahiq dan non mustahiq dari sudut pandang pemeliharaan akal

\begin{tabular}{l|l|l|l}
\hline Total Mustahiq & 128 & Total Mustahiq & 79 \\
\hline Presentasi & 85,3333 & Presentasi & 52,6667 \\
\hline
\end{tabular}

Tabel di atas diperoleh hasil persentase kesejahteraan mustahiq dari sudut pandang pemeliharaan akal sebesar 85,3\%, sedangkan hasil untuk non mustahiq adalah sebesar 52,6\%. Perbedaan keduanya cukup signifikan sehingga variabel pemeliharaan akal pada zakat maupun bantuan non zakat berbeda dalam memberikan pemeliharaan akal kepada mustahiq dan non mustahiq. Sehingga zakat memberikan kesejahteraan lebih tinggi pada aspek akal dari pada bantuan non zakat.

Tabel 4.18 Perbedaan persentase kesejahteraan mustahiq dan non mustahiq dari sudut pandang pemeliharaan jiwa

\begin{tabular}{l|l|l|l}
\hline Total Mustahiq & 145 & Total Non Mustahiq & 97 \\
\hline Presentasi & 96,6667 & Presentasi & 64,6667 \\
\hline
\end{tabular}


Roisiyatin,: zakat; welfare; mustahiq.

Tabel di atas diperoleh hasil persentase kesejahteraan mustahiq dari sudut pandang pemeliharaan jiwa sebesar $96,6 \%$, sedangkan hasil untuk non mustahiq adalah sebesar 64,6\%. Perbedaan keduanya cukup signifikan sehingga variabel pemeliharaan jiwa pada zakat maupun bantuan non zakat berbeda dalam memberikan pemeliharaan jiwa kepada mustahiq dan non mustahiq. Sehingga zakat memberikan kesejahteraan lebih tinggi pada aspek jiwa dari pada bantuan non zakat.

Tabel 4.19 Perbedaan persentase kesejahteraan mustahiq dan non mustahiq dari sudut pandang pemeliharaan harta

\begin{tabular}{l|l|l|l}
\hline Total Mustahiq & 134 & $\begin{array}{l}\text { Total Non } \\
\text { Mustahiq }\end{array}$ & 60 \\
\hline Presentasi & 89,33333 & Presentasi & 40 \\
\hline
\end{tabular}

Tabel di atas diperoleh hasil persentase kesejahteraan mustahiq dari sudut pandang pemeliharaan harta sebesar 89,3\%, sedangkan hasil untuk non mustahiq adalah sebesar $40 \%$. Perbedaan keduanya sangat signifikan sehingga variabel pemeliharaan harta pada zakat maupun bantuan non zakat berbeda dalam memberikan pemeliharaan harta kepada mustahiq dan non mustahiq. Sehingga zakat memberikan kesejahteraan lebih tinggi pada aspek harta dari pada bantuan non zakat.

Tabel 4.20 Perbedaan persentase kesejahteraan mustahiq dan non mustahiq dari sudut pandang pemeliharaan keturunan

\begin{tabular}{l|l|l|l}
\hline Total Mustahiq & 108 & $\begin{array}{l}\text { Total Non } \\
\text { Mustahiq }\end{array}$ & 55 \\
\hline Presentasi & 72 & Presentasi & 36,66667 \\
\hline
\end{tabular}

Tabel di atas diperoleh hasil persentase kesejahteraan mustahiq dari sudut pandang pemeliharaan keturunan termasuk di dalamnya faktor kelestarian lingkungan sebesar $72 \%$, sedangkan hasil untuk non mustahiq adalah sebesar 36,6\%. Perbedaan keduanya cukup sehingga variabel pemeliharaan keturunan pada zakat maupun bantuan non zakat berbeda dalam memberikan pemeliharaan keturunan kepada mustahiq dan non mustahiq. Sehingga zakat memberikan kesejahteraan cukup tinggi pada 
aspek keturunan dari pada bantuan non zakat Maka, hasil analisis dari uji beda yang dilakukan dengan analisis anova dinyatakan bahwa pemberian dana zakat dan pembinaan yang dilakukan memberikan kontribusi kesejahteraan dengan persentase $87 \%$ dari total kesejahteraan 100\%. Sedangkan kesejahteraan non mustahiq dengan sasaran dan treatment yang hampir serupa dengan bantuan zakat memberikan kesejahteraan dengan persentase 59\% dari total kesejahteraan 100\%. Maka, kesimpulan dari penelitian ini adalah bahwa terdapat perbedaan kesejahteraan antara mustahiq dan non mustahiq. Sehingga dari sudut pandang maqaashidus syariah diketahui bahwa secara perhitungan maqaashidus syariah zakat memberikan kesejahteraan secara agama, akal, jiwa, harta dan keturunan termasuk di dalamnya unsur lingkungan yang sering diabaikan. Zakat sebagai salah satu syariat yang ditetapkan Allah SWT untuk kemaslahatan umat manusia dapat memenuhi kelima aspek maqaashidus syariah dalam studi kasus yang dilakukan pada mustahiq Program Pemberdayaan Petani Sehat Klaster Mandiri Dompet Dhuafa dan non mustahiq Program Nasional Pemberdayaan Masyarakat.

\section{KESIMPULAN}

Hasil penelitian tentang analisis zakat terhadap kesejahteraan mustahiq dan non mustahiq perspektif maqaashidus syariah (Studi kasus pada Program Permberdayaan Petani Sehat (P3S) Gapoktan Al-Ikhwan Dompet Dhuafa dan Program Nasional Pemberdayaan Masyarakat (PNPM) adalah sebagai berikut: dari hasil uji beda anova diketahui bahwa tingkat signifikansi adalah 0,010 yang berada di bawah 0,05, artinya terdapat perbedaan signifikan antara variabel bantuan zakat $(X)$ terhadap kesejahteraan mustahiq dari sudut pandang maqaashidus syariah (Y) dibandingkan dengan bantuan kepada non mustahiq. 
Roisiyatin,: zakat; welfare; mustahiq.

\section{DAFTAR PUSTAKA}

Aflah, Noor. (2009). Arsitektur Zakat Indonesia. Jakarta: UI Press.

Al-Qurtubi. (1411). al-jami' Li Ahkam Al-qur'an. Beirut Libanon: Daar el-Kutub ‘Ilmiyyah 1413 H/1993M Jilid VII-VIII.

Ali, Muhammad Daud. (1998). Sistem Ekonomi Islam Zakat dan Wakaf. Jakarta: UI Press.

Amin, Ruzita Mohd. The integrated Development Index (I-Dex): A New Comprehensive Approach To Measuring Human Development. Research

Azka, Abu Lukman Mohammad Baga. Sari Penting Kitab Fiqih Zakat

Yusuf Al-Qaradhawy (e-book). New Zealand: Dept. of Agr. Economics and Business, Massey UniversityPalmerston North.

Billah, Mohd Ma'sum. (2009). Penerapan Hukum Dagang dan Keuangan Islam.

Malaysia: Sweet \& Maxwell Asia. Chapra, Umer. (2000). Islam dan pembangunan ekonomi.Jakarta: gema insani Press.

El-Diwany, Tarek. (2008). The Problem With Interest. Jakarta: Akbar Media Eka Sarana.

Hafidhuddin, Didin. (2002). Zakat Dalam Perekonomian Modern. Jakarta: Gema Insani Press.

Huda, Nurul, dkk. (2008). Ekonomi Makro Islam . Jakarta: Kencana.

Kahf, Monzer. (1955). Ekonomi Islam: Telaah Anlitik Terhadap Fungsi Sistem Ekonomi Islam. Yogyakarta: Pustaka Pelajar.

Kurniawati. (2004). Kedermawanan Kaum Muslimin. Piramedia.

Mahmudi. (2009). Sistem Akuntansi Organisasi Pengelola Zakat. Yogyakarta: Pusat Pengkajian dan Pengembangan Ekonomi Islam Fakultas Ekonomi Universitas Islam Indonesia.

Mannan, MA. Islamics Economics, Theories and Practices. Lahore: Sh Muhammad Ashraf Publishers.

Mufraini, Arif. (2006). Akuntansi dan Manejmen Zakat (Cetakan Pertama). Jakarta: Kencana Prenada Media Group. 
Muhammad, Abdul Aziz bin. (1993). Zakat and Rural Development in Malysia. Kuala Lumpur: Berita Publishing.

Price, Colin dan Miller. (1991). Debt and The Environment: Converging

Crises. Prihartini, Farida. 2005. Hukum Islam Zakat dan Wakaf. Jakarta: Papas Sinar Sinanti dan UI Press.

Qadir, Abdurrahman. (1998). Zakat Dalam Dimensi Mahdhah dan Sosial. Jakarta: PT Raja Grafindo Persada.

Qardhawi, Yusuf. (2005). Spektrum Zakat. Daar El-Syoruk. Qardhawi, Yusuf. 1991. Fiqh Zakat, Beirut: Muassasah Risalah. Sabiq, Sayyid. 1968. Figh Sunnah. Kuwait: Daar El-Bayan.

Saefuddin, Ahmad Muflih. (1986). Pengelolaan Zakat Ditinjau Dari Aspek Ekonomi. Bontang: Badan Dakwah Islamiyyah, LNG.

Saud, Mahmoud Abu. ( 1998 ).Contemporar Zakat, Zakat and Research Foundation, Ohio.

Shad, Abdur Rahma. (1986). Zakat and Ushr. Lahore: Kazi Publication.Soddy, Frederick. 1933. Money versus Man

Tim Dompet Dhuafa. (2009). Indonesia Zakat \& Development Report: Zakat dan Pembangunan: Era Baru Zakat Menuju Kesejahteraan Ummat, kerjasama Dompet Dhuafa Republika dan Pusat Ekonomi dan Bisnis Syariah Universitas Indonesia.

Wibisono, Yusuf. (2012). Masa Depan Pengelolaan Zakat Nasional Pasca UU No. 23 Tahun 2011. Makalah disampaikan pada Public Expose "Indonesia Zakat and Development Report 2012" diselenggarakan oleh IMZ Jakarta, 30 Januari 2012. 